\title{
Did Pakistanis Vote for the Status Quo?
}

\author{
Omer Bin Abdullah
}

\begin{abstract}
The latest - and possibly the last - period of military rule in Pakistan ended in 2008, when elections were held under the thendictator General Pervez Musharraf. The voting sprouted a coalition government headed by the Pakistan Peoples Party that ruled (or rather riled) the country for five excruciating years. The ever-erring ruling group included the Pakistan Muslim LeagueNawaz, one of the many breakaway wings of the country's founding political movement.
\end{abstract}

The country has suffered ever since the Soviets invaded neighboring Afghanistan, leading the United States and its allies to fund the "mujahideen," the tribal-based loosely organized Muslim fighters from all over the world. After 9/11, President George W. Bush's attack on Afghanistan and hot pursuit of targets inside Pakistan, not to mention the military dictator Musharraf's wholesale willingness to support the United States in all of its decisions, has led to high levels of violence and instability.

The Pakistani political establishment has little to show for its efforts. However, another development took root seventeen years ago. Imran Khan, the internationally respected and loved sports heroturned-philanthropist, realizing that acts of kindness alone would not heal the country's malaise, launched his own political party in a quest for justice and equality in a society firmly controlled by the feudal landed class created by the British to rule the Subcontinent. After ignoring him for some fifteen years, despite his many sacrifices, the nation finally heard him. But while his popularity boomed in 2011, his attempt to empower the masses by bringing in "fresh blood," namely, young educated people, women, and even the poor into the assemblies failed. The voters were, as many Pakistanis believe, deprived of their choice, and thus the same exploitative feudal

Omar Bin Abdullah is the editor of Islamic Horizons and a long-time observer of Pakistan's sociopolitical scene. He has an M.A. in journalism from Syracuse University, New York. This article does not represent the views of Islamic Horizons or the Islamic Society of North America (ISNA). 
class was returned to power. Khan has not fared too well, but at least he has planted the seeds of inclusive participation. Whether he can sustain it, however, remains to be seen.

\section{Introduction}

Not everyone in Pakistan believes that they have spoken. According to the Election Commission of Pakistan (ECP), some 60 percent of the country's 86 million registered voters voted, including a large number of women, ${ }^{1}$ despite fears of violence. ${ }^{2}$ Widespread post-election protests indicate that their "voice" was qualified. ${ }^{3}$

Nothing else can explain why the Pakistan Muslim League-Nawaz (PML-N), a Nawaz Sharif-led breakaway group of the original Pakistan Mus$\lim$ League $^{4}$ that for five years had partnered with the utterly corrupt Pakistan People Party (which some call the "Plunder Pakistan Party"), secured a huge landslide in the National (Federal Lower House) Assembly and in the Punjab Provincial (State) Assembly. In comparison to this landslide, the wildly popular Pakistan Tehreek Insaf (PTI; Pakistan Justice Movement), led by the internationally loved and renowned sports hero-turned-philanthropist and Oxford-educated political leader Imran Khan, secured only twenty-eight national assembly seats. As per the Pakistani constitution, the seats reserved for women, minorities, and other population groups are awarded to each party in proportion to the number of seats they win. To win an outright majority, a party must obtain $50 \%+1$ of the total seats $(272+$ reserved $) .{ }^{5}$ This will once again favor the PML-N, the largest party bloc, with an additional chunk of most of these seventy reserved seats.

Not only PTI supporters, but even others joined massive sit-ins asking for their will to be respected. ${ }^{6}$ In areas predicted to massively support the PTI, voters were made to wait in line for more than ten hours in the $95^{\circ} \mathrm{F}$ heat, and even above in some areas, and then turned away without being allowed to cast their votes. In some cases, the stamped ballot papers were snatched and torn-up before they could be dropped into the transparent plastic ballot box. ${ }^{7}$ Also, in many areas the ballot boxes were looted and destroyed and the polling stations were locked up, thereby allowing some candidates to stuff the ballot boxes. ${ }^{8}$ And then there are charges that the other parties, except for the PTI, were buying votes and that officials were dispensing cash like running water.

The Human Rights Commission of Pakistan, commenting on the elections, declared: “...the Elections of 2013 were the costliest in the country's history, in addition to being the most grossly mismanaged by the Election Commission of Pakistan (ECP)." 


\section{A Sorry History of Political Impunity}

In recent years, Pakistan, despite having more than 100 officially registered political parties, has sauntered into being a two-party affair: the PML-N and the PPP rule alternatively; sometimes they even share power. A short review of the country's political history reveals how the dream of a truly democratic Pakistan was destroyed soon after its birth.

At its founding in 1947, the departing British colonial rulers granted Pakistan a rather unique arrangement: a country composed of two geographically separated wings. East Bengal, which eventually became East Pakistan, contained more than 50 percent of the country's population; located nearly 1,000 miles to the west was West Pakistan, comprising West Punjab, Sind, Baluchistan, the North West Frontier Province (later renamed Khyber Pakhtunkhwa). As the British had mainly used Punjab for recruiting the cannon fodder needed for its colonial expansion in the region and elsewhere, the new country's power rested primarily on this province, an unfortunate development that led to the appearance of a sense of deprivation within other provinces. This dissatisfaction ultimately led to East Pakistan's secession in 1971.

The country's founder, Mahomed Ali Jinnah, died soon after independence. His successor Liaquat Ali Khan was assassinated in 1953 in Rawalpindi, now a twin city with the nation's capital: Islamabad. After this event, the rot began to set in.

After a spell of short-lived and incessantly squabbling civilian governments, which took nine years to adopt a constitution (1956), the military commander and later self-styled field marshal Ayub Khan staged the country's first military coup. ${ }^{10}$ After eleven years of rule, during which his family enriched themselves at will, ${ }^{11}$ he handed power over to his handpicked successor General Yahya Khan, who was more inclined to pursue women and alcohol than affairs of state. And he, in his turn, left another legacy: Zulfikar Ali Bhutto, a debauchee and power-hungry manipulator. ${ }^{12}$ After the controversial presidential elections of 1965, Ayub's standing began to slide amidst allegations of widespread vote rigging. His former protégé Bhutto took full advantage of this and propelled himself to the forefront.

In 1965, Bhutto developed a novel scheme to upset his mentor: he helped initiate a war with India, hoping that the ensuing defeat would weaken General Khan and help him rise to the top. ${ }^{13}$ After being fired, Bhutto launched the Pakistan People's Party (PPP). An astute speaker, he was able to rouse the masses with promises of providing them with the basic necessities of life. But after the country split in half, since both Yahya Khan and Bhutto refused to 
recognize the Awami League's winning a majority of seats in East Pakistan, the latter came to power by default because he led the largest group in Parliament of what was left of the country. Bhutto kept none of his promises, his skewed economic policies destroyed the country's industrial and financial base, and widespread corruption became the order of the day.

Under his rule, this believer in absolute power who lusted after power in order to keep everyone's life under his control destroyed whatever industrial and commercial base had been built. After he rigged the 1977 elections in order to win a two-thirds majority, civil disorder broke out and his own handpicked commander-in-chief, Ziaul Haq, overthrew him. Zia, who originally took office for a 90-day cleansing period, stayed in power until 1988, when he and several generals were killed in a still-mysterious plane crash.

The 1988 elections led to the PPP securing ninety-four of the 207 seats in the National Assembly. Acting President Ghulam Ishaq Khan invited it to form a government, and its leader Benazir Bhutto (1953-2007), Zulfikar Ali Bhutto's daughter, became the Muslim world's first-ever female prime minister. Like her father's misrule, Benazir's rule was also marked by large-scale corruption. After she was dismissed in 1990 on corruption charges, her husband Asif Ali Zardari was held from 1990-93 on various corruption charges; he was eventually acquitted.

Corruption was rife. In fact, Benazir had appointed her husband environment minister (1993-96) and minister for investment (1995-96). In 1996, when her handpicked president Farooq Laghari dismissed her government on corruption charges, Zardari was accused of having taken kickbacks (by then he had acquired the nickname "Mr. Ten Percent"14) and of having ordered the murder of Bhutto's brother, a political opponent. He was again imprisoned, briefly in 1996 and from 1997 to 2004. Bhutto and Zardari also were convicted (1999) of corruption and embezzlement; Pakistan's Supreme Court ordered a new trial in 2001. A Swiss court convicted the couple of money laundering in 2003, but they appealed.

The corruption cases against them and thousands of other PPP and coalition partners were set aside by the National Reconciliation Order issued in December 2009 by General Musharraf, acting under former president George W. Bush's pressure.$^{15}$ However, the Supreme Court later rejected Musharraf's act on the grounds that it was essentially writing off billions of stolen dollars. ${ }^{16}$ Zardari ${ }^{17}$ denied the charges and denounced them as politically motivated. But after becoming president, he told the Supreme Court to release the $\$ 60$ million account in a Swiss bank - money allegedly siphoned off from a contract given to a Swiss firm. ${ }^{18}$ 
During the 1990s Nawaz Sharif, who led his own faction of the Pakistan Muslim League, the party that had struggled for Pakistan's creation, also served two prime ministerial stints. His first term was aborted by President Ishaq Khan, and his second term started after his electoral victory in 1997. In 1999, Sharif's handpicked commander-in-chief, General Musharraf, ousted him in a yet another military coup. ${ }^{19}$

\section{The Current Players}

General Haq, at first scorned by the West for being a dictator, became the apple of his critics' eyes when the Soviets invaded Afghanistan, for he allowed Pakistan to serve as the base to channel arms and fighters into its neighbor. While the West and its Muslim allies, most notably Saudi Arabia, subcontracted the actual fighting to randomly recruited fundamentalist and other zealous Muslims, these mujahideen's eventual triumph over the Soviet army led to the Soviet collapse. But it also had an unintended side effect: It destroyed the Pakistan that its people had known up to that point in time by reducing to an international base for terrorists, an object of death and destruction, and a plaything of the West.

Haq had nurtured a civilian protégé, Nawaz Sharif, a person regarded by many Pakistanis as a man of limited intelligence and skills. ${ }^{20}$ He now appointed this man to the post of a provincial finance minister. Sharif's father, a self-made industrial tycoon, and his son's foray into politics helped the Sharif enterprise expand astronomically. ${ }^{21}$ Both Nawaz and Benazir had two lucrative stints in office, each accusing the other of corruption.

Over five years ago, General Musharraf, bowing to the pressure applied by George W. Bush, pardoned Benazir and her group's corruption and crimes by issuing the National Reconciliation Order (NRO; later voided by the Supreme Court), which allowed Benazir to return to politics. ${ }^{22}$ Sharif followed soon thereafter. In the run up to the 2008 elections, Benazir was assassinated - a mystery that remains unsolved despite her party's five years in power. The PTI and the other parties boycotted the election because it was held under the NRO, but the PML-N broke ranks and participated.

The election produced a mixed Parliament: at the federal level, the PPP teamed up with three smaller parties and the ever-available opportunists. The result was a five-year period of mismanagement and corruption during which most of the public institutions were robbed and bankrupted. ${ }^{23}$ Zardari, the largest bagger of goodies, added to his earlier loot during his wife's two terms in office. Among his latest picking was a $\$ 50$ million mansion ${ }^{24}$ in Lahore 
"presented" to his son by an "uncle," described as the country's largest and most ruthless real estate tycoon, in early $2013 .{ }^{25}$

In Punjab, the PLM-N, which had never seriously challenged the PPP, partnered with it to run the province. In keeping with its style, the PML-N focused only on short-term projects, usually those attention-grabbing ones that could be completed in time for elections. ${ }^{26}$ For instance, instead of investing in agricultural development, especially since Punjab has a heavily agricultural economy, the PML-N provincial government lavished tens of millions of rupees on subsidized bread. Also, instead of raising educational standards and facilities, the leading politicians started giving away free laptops. Such stopgap measures do garner votes, but they also waste the much-needed development funds.

Great numbers of ordinary Pakistanis were fed up with these usual tactics, as evidenced by the tens of thousands of them who attended Imran's raucous rallies. But despite this groundswell, various opinion surveys indicated that Sharif would win by a landslide. ${ }^{27}$ While this indicated that Imran had energized the traditionally disfranchised economic and social classes, he was unable to attract sufficient numbers of "electables," namely, the mostly hereditary feudal politicians and "spiritual" leaders. In reality, these were the real or claimed descendants of those Muslims who had come to preach in India centuries ago and came to be revered by the people. They are constantly returned to the provincial assemblies, regardless of the party they may be representing or how they lead their personal lives, and demand a price for their services. In fact, they maintain that it is their birthright to stand for election in their hereditary constituencies.

But Imran, a firm opponent of such traditional privilege, was determined to end the reign of such exploiters by placing actual power in the hands of the people. Initially sensing that Imran was a rising star, quite a few such "electables" joined his party. But they left, often badmouthing him, as soon as they realized that their supposed birthright counted for nothing in this new party. Ironically, it was these many party hoppers who were returned to assemblies, often thrashing the personally upright and qualified candidates fielded by the PTI. The status quo worked, or perhaps it would be more accurate to say that it was engineered.

PTI president Javed Hashmi has said that the party is collecting evidence of massive nationwide irregularities and vote rigging. Addressing a press conference on May 13, 2013, he said: "We will bring out a white paper on the massive rigging in polling after gathering evidence." ${ }^{28}$ After much criticism, the ECP has asked the National Database and Registration Authority (NADRA) 
to help verify votes by matching thumbprints with its database; its software can verify 500,000 votes per day. ${ }^{29}$ However, the question remains how far this will proceed once the victors are in power.

And yet there is some solace: A party that had secured only one seat, that of Imran, in the 2002 assembly and had boycotted the 2008 elections now rules Khyber Pakhtoonkhwa (KPK) province. Since day one, Imran had stated his principles in the following terms. If he failed to secure a clear majority, he would not form a coalition government with any of the parties that had ruled during the past five years and those that maintain armed wings. He had also repeatedly declared that he does not consider Zardari's election as president legal because he obtained the office via the (now illegal) NRO. Thus even if he had secured a majority in the National Assembly, he would have refused to take the oath from Zardari, who remains in office until September 2013.

Similarly, the PTI has fewer National Assembly seats than the PPP. The PTI, firm on its principle of not dealing with parties that had riled the country for the last five years, could not form the coalition needed for claiming the leader of opposition position. Under Pakistani parliamentary procedures, the PPP's Syed Khursheed Shah took this slot, and thus the authority to make committee appointments. The party promptly appointed Zardari's sister, Dr. Azra Afzal Pechuho, as the Public Accounts Committee (PAC) chairperson. The parliamentary watchdog is responsible for auditing funds appropriated by the National Assembly. During its last tenure, the PPP created the precedant of having the opposition leader - or his/her nominee - serve as the PAC's chairperson. Considering the PPP's penchant for corruption, what hopes can the public hold that these two cannot outnumber the PPP-led coalition, which could include their partners in the past government? $?^{30}$

When Nawaz visited Imran in the hospital ${ }^{31}$ - he is recuperating from an accidental fall - on May 14, Imran reminded him of the hadith that Muslims must shed their anger toward each other within three days. Nawaz agreed. The PTI, which leads in the KPK, has established the provincial government in coalition with the JI and others. The PTI has 34 of the 95 seats, the JI and the Quami Watan Party have 7 each, while the 8 independents can make their own choice. Under the Eighteenth Constitutional Amendment, the independent MPs have to join a political party within three days after the ECP notifies them of who won the election; otherwise, they must stay independent and cannot join any party at later stage. ${ }^{32}$ But unlike the 2008 post-election scenario, the PML-N does not need them because it has a near simple majority in the National Assembly and more than the number required for forming a government in Punjab. 


\section{Raising the Nation}

Imran, in his time the cricket world's best all-rounder - as he had promised to himself - retired aged thirty-nine and at the top of his game. In 1992, the country's president pressured him to return and play one more World Cup. Pakistan won, and Imran utilized his fame to fulfill his pledge that he had made after seeing his mother suffer from cancer: He would build the country's first worldclass charitable specialist cancer hospital. In addition, he is perhaps the only Pakistani leader who published his autobiography prior to launching his election campaign. ${ }^{33}$ The people, especially the youth, answered the call and the people-financed hospital in Lahore has become a reality. A second such facility is nearing completion in Peshawar, and a tract of land in Karachi awaits the third hospital.

Educated at the country's most exclusive private school, Lahore's Aitchison College (also known as Chief's College) ${ }^{34}$ Imran wanted to place that level of education within everyone's reach. Toward this end, he established Namal University in one of the country's most neglected areas - not too far from where American drones keep dropping their payloads. Affiliated with Britain's Bradford University, it provides that level of higher education at a nominal cost. However, he feels that such philanthropy alone cannot answer Pakistan's myriad problems. In fact, he strongly believes that nothing can be straightened out in the absence of an effective and uncorrupted legal system. ${ }^{35}$

When he launched the PTI in 1996, Imran became a laughingstock, for no one could visualize that this shy sportsman could lead a party, let alone Pakistan. The price was steep ${ }^{36}$ : his political opponents, especially PML-N chief Nawaz Sharif - who has headed the Punjab and federal governments on five occasions - ruthlessly targeted him and managed to destroy his family life. In 1995, Imran had married heiress Jemima Goldsmith, a British convert. She was labeled a "Jewess" and an "Israeli agent," and even charged with smuggling tiles that she had obtained for the house they were building in suburban Islamabad. Unable to take such pressure, Jemima, now the mother of two sons, returned to Britain in 2004 and arranged an amicable divorce.

Like most Pakistanis, Imran also knew that the stranglehold of corruption and injustice could be broken only by ousting the feudal landlords (created by the British), who have engaged in every unimaginable trick to cling to power in order to quench their insatiable thirst for power and wealth. Since it became independent sixty-five years ago, Pakistan has been ruled by four military dictators: M. Ayub Khan (1958-69), Agha Yahya Khan (1969-71), M. Ziaul Haq (1977-88), and Pervez Musharraf(1999-2008) - inglorious periods by any count. Such corruption and mismanagement has forced this nuclear 
power to beg from all and sundry, ${ }^{37}$ which has led to its recent, and now complete, subjugation to the dictates of foreign powers, whether they have its best interests at heart or not.

Pakistan is also plagued by foreign intervention. The Soviet occupation of neighboring Afghanistan and the skewed western response destroyed its civil structure. Another shattering blow to its stability was delivered by the post-9/11 western response in Afghanistan. Now the country is being ravaged by terrorism, drone bombing, and political and economic instability.

Imran vociferously opposes the drone campaign ${ }^{38}$ and Pakistani ownership of the war in Afghanistan, stressing that these actions have not only cost thousands of innocent Pakistani lives, but are also the main reason for the deadly violence raging throughout the country. Sharif has maintained an ambiguous stance on this particular issue. Understandably, the moment the election results indicated a swing toward Sharif, an impatient Barack Obama ${ }^{39}$ and David Cameron ${ }^{40}$ did their best to congratulate and build him up; they even praised his economic policies. Secretary of State John Kerry is ready to travel there to meet the new team. ${ }^{41}$

This also indicates that the drone strikes will probably continue, as well as the overwhelmingly negative reaction to them. ${ }^{42}$ While Britain has maintained that the drone issue was a bilateral Pakistani-American matter, the Guardian's Jamie Doward ${ }^{43}$ revealed that Britain, which is also involved in the drone warfare, ${ }^{44}$ has been forced to admit that it has been funding surveys in the Federally Administered Tribal Areas that reveal that American drone strikes in the region are causing deep resentment among the local population.

\section{The 2013 Elections}

Most political parties in Pakistan, including the PML-N and the PPP, are in fact merely family-owned and -operated self-enrichment corporations that distribute nominations for elections to family ${ }^{45}$ and friends. ${ }^{46}$ Even the constitutional requirements for elected party officials is a farce. ${ }^{47}$ Imran, seeking genuine grassroots representation, flouted this norm by seeking nominees who had been elected by their peers as well as candidates who had unblemished tax records and personal histories. During October 2011, his dream finally materialized when more than 100,000 citizens answered his call at a rally in Lahore, the capital city of Punjab and home to nearly 60 percent of all Pakistanis - and the momentum continued to rise. ${ }^{48}$ This led to mass membership drives, which resulted in a total of more than 10 million members. The 80,000 
councilors, all of whom were elected from the village level, then recommended nominees to the party's election board. An example of transparency is that when the nomination papers of Imran's paternal cousin and founding member ${ }^{49}$ were put up for discussion, Imran not only recused himself, but also took no action - even when the board ruled against his cousin.

Unfortunately, managing a nationwide electoral campaign for so many councilors took far more effort and time than the party had originally envisaged. Due to the delays in the nomination process, the candidates were left with little time to canvass their voters. Some political commentators are calling this a grievous mistake on Imran's part.

As things now stand, PTI supporters remain in a state of shock. However, some political commentators have pointed out that Sharif has promised far too much,$^{50}$ such as running a bullet train from Peshawar to Karachi, a project that would cost tens of billions of dollars that a financially strapped country with such low tax revenues cannot possibly afford..$^{51}$ Such reality-defying promises may, before two years, result in calls for another election. Just to start addressing some these promises, Sharif will have to tackle the severe power shortages that damage the already aid-dependent economy ${ }^{52}$ and hold back job creation things the party sidestepped during its previous five-year rule.

\section{Conclusion}

Imran is perhaps the only Pakistani leader who published his autobiography prior to launching his election campaign. ${ }^{53}$ His call was answered by all levels of professionals, especially IT specialists and those enjoying well-paid jobs overseas. Most famously, the CEO of a Pakistani corporation left his reportedly $\$ 1$ million-a-year job to join the ranks. ${ }^{54}$ The PTI ran a fabulous media and social media campaign, and Imran, being a national treasure, was the political leader most often invited by the dozens of television broadcasters to appear on their programs. He also fulfilled his promise that his party would give 35 percent of its nominations to men and women below the age of forty, irrespective of their social and financial status. ${ }^{55}$ The party even financed the campaigns of its low-income candidates. While Imran has failed to break the stranglehold of the feudal class,${ }^{56}$ many of whom, ironically, are his schoolmates, he has given a base to popular involvement in national affairs.

Irrespective of the national and provincial assemblies' final composition, Imran has created a hitherto unknown political awareness among all social strata, especially young voters. Women, defying the vigilante action 
of some tribal and self-styled religious groups, turned up in large numbers to vote. When the much-awaited voting system for overseas Pakistanis was not readied in time, tens of thousands flew in to vote, and mostly voted for the PTI.

In his concession speech from his hospital bed - he is being treated for an accidental fall from a lift raising him to a 20-foot-high platform - Imran proclaimed: "I congratulate the entire nation for taking part in such a massive democratic process. We are moving forward on the path of democracy." He then added: "Even those people who never voted in their life came out, and the entire nation is happy to see it. Now there is an awareness among the people of Pakistan that their fate is in their hands." 57

Herein lies the challenge for Imran: Will he be able to hold his party together, whose numbers grew so remarkably after October 2011, and maintain the energies of the youth whom he did so much to empower?

\section{Endnotes}

1. "Pakistanis Stream to Polls Despite Threats of Violence," Reuters, Atif Raza and Munir Ahmed, 11 May 2013, http:/talkingpointsmemo.com/news/pakistanisstream-to-polls-despite-threats-of-violence.php (accessed 15 May 2013).

2. Pakistani general election, 15 May 2013, http://en.wikipedia.org/wiki/Pakistani_ general_election,_2013.

3. "Post-poll protest: PTI supporters take to the streets," Express Tribune, 12 May 2013, Karachi, http://tribune.com.pk/story/548291/post-election-protest-pti-supporters-take-to-the-streets/ (accessed 15 May 2013).

4. Pakistan Muslim League, http://en.wikipedia.org/wiki/Pakistan_Muslim_ League (accessed 15 May 2013).

5. "President signs amendment, 4 seats for non-Muslims," Express Tribune, 26 Aug. 2011, Karachi, http://tribune.com.pk/story/239581/non-muslims-to-havefour-seats-reserved-in-senate/ (accessed 15 May 2013).

6. "PTI wants recount with fingerprint verification in 4 constituencies," 15 May 2013, Express Tribune, Karachi, http://tribune. com.pk/story/549601/pti-wantsrecount-with-fingerprint-verification-in-4-constituencies/ (accessed May 16, 2013).

7. "15 Election Rigging Videos from Pakistan That Went Viral on Social Media!" Mehwish Khan, 11 May 2013, http://propakistani.pk/2013/ 05/11/election-rigging-videos-and-images-go-viral-on-social-media/ (accessed 15 May 2013).

8. "Imran Khan backers protest Nawaz Sharif's Pakistan election win," Affan Chowdhry, Lahore, Globe and Mail, 13 May 2013, http://m.theglobeandmail. com/news/world/imran-khan-backers-protest-nawaz-sharifs-pakistan-electionwin/article11883736/?service=mobile (accessed 15 May 2013). 
9. "Flaws in Elections 2013 highlighted by HRCP," http://www.outlookpakistan. com/2013/05/13/flaws-in-elections-2013-highlighted-by-hrcp/ (accessed 15 May 2013).

10. October 28, 1958.

11. "Details of Gohar Ayub Khan" PakistanHerald.com, http://www.pakistanherald. com/Profile/Gohar-Ayub-Khan-514 (accessed 15 May 2013).

12. "Zulfiqar Ali Bhutto: Like him or not, the man was extraordinary," Abdul Majeed, 4 Apr. 2013, Express Tribune Blogs (accessed 15 May 2013).

13. "1965 War: Operation Gibraltar - Role of SSG Para Commandos," Col. S. G. Mehdi, MC, http://www.defencejournal.com/july98/1965war.htm (accessed 15 May 2013).

14. http://www.bbc.co.uk/news/world-asia-16066406 (accessed 15 May 2013).

15. “Pakistan's Democracy Movement Flexes its Muscles," Tom Burghardt, Global Research, 23 Mar. 2009, http://www.globalresearch.ca/pakistan-s-democracymovement-flexes-its-muscles/?print=1 (accessed 15 May 2013).

16. Supreme Court releases detailed ruling in National Reconciliation Ordinance case. The Free Library, 15 May 2013, http://www.thefreelibrary.com/Supreme+ Court+releases+detailed+ruling+in+National+Reconciliation...-a0216998629.

17. [U.S. Senate] "Minority Staff Report for Permanent Subcommittee on Investigations: Hearing on Private Banking and Money Laundering: A Case Study of Opportunities and Vulnerabilities," 9 Nov. 1999. See: (2) Asif Ali Zardari Case History http://archive.is/4eFdG.

18. Asif Ali Zardari, http://en.wikipedia.org/wiki/Asif_Ali_Zardari (accessed 15 May 2013).

19. "U.S. caught by surprise by Pakistan coup," 12 Oct. 1999, CNN, http://www. cnn.com/US/9910/12/us.pakistan.02/ (accessed 15 May 2013).

20. http://www.defence.pk/forums/national-political-issues/245959-some-factsabout-nawaz-sharif-nick-name-kuggo.html (accessed 15 May 2013).

21. "Meet The New Boss, Same As The Old Boss: Who Is Nawaz Sharif, Pakistan's New Leader?", Palash Ghosh, International Business Times, 13 May 2013, http://www.ibtimes.com/meet-new-boss-same-old-boss-who-nawaz-sharifpakistans-new-leader-1254205\# (accessed 16 May 2013).

22. "Pakistan's president under pressure after ruling," 17 Dec. 2009, USA Today, http://usatoday30.usatoday.com/news/world/2009-12-16-pakistan-presidentamnesty_N.htm (accessed 15 May 12013).

23. "Railways, PIA facing huge losses, Senate told," Amir Wasim, Dawn, Karachi, 20 Dec. 2012, http://dawn.com/2012/ 12/20/railways-pia-facing-huge-lossessenate-told/ (accessed 16 May 2013).

24. "Transparency raises questions about Rs5 bn Bilawal House in Lahore," 14 Feb. 2013, http://www.thenews.com.pk/Todays-News-13-20957-Transparency-raisesquestions-about-Rs5-bn-Bilawal-House-in- Lahore (accessed 15 May 2013).

25. "Young Bilawal gets a sprawling house in Lahore," Mubashir Hassan, Nation, Lahore, 27 Feb. 2013. http://www. nation.com.pk/pakistan-news-newspaper- 
daily-english-online/national/07-Feb-2013/young-bilawal-gets-a-sprawlinghouse-in-lahore (accessed 15 May 2013).

26. "Sharifs hope to ride transit scheme to victory," Affan Chowdhry, Globe and Mail, Toronto, 25 Apr. 2013, http:// www.theglobeandmail.com/news/world/ sharifs-hope-to-ride-transit-scheme-to-victory/article11562322/ (accessed 15 May 2013).

27. "PTI urges ECP to take notice of Gallup's 'misguiding poll'," 26 Apr. 2013, News, Karachi, http://www.thenews.com.pk/Todays-News-6-173521-PTIurges-ECP-to-take-notice-of-Gallups-misguiding-poll (accessed 15 May 2013).

28. "PTI to issue white paper on rigging: Hashmi," Imaduddin, 14 May 2013, Business Recorder, Karachi, http://www.brecorder.com/elections-2013/top-news/ 119513-pti-to-issue-white-paper-on-rigging-hashmi.html (accessed 15 May 2013).

29. “ECP asks NADRA to help verify voters' thumbprints," Express Tribune, Lahore, 20 May 2013, http://ribune.com.pk/story/551882/ecp-asks-nadra-to-helpverify-thumbprints/ (accessed 20 May 2013).

30. http://www.dailytimes.com.pk/default.asp?page=2013 \06 $\backslash 10 \backslash$ story_10-62013 _pg7_14, Daily Times, Lahore, 10 Jun. 2013 (accessed 10 Jun. 2013).

31. "Bouquet diplomacy: Nawaz offers, Imran accepts hatchet-burying offer," Abdul Mannan, Express Tribune, Karachi, 15 May 2013, http://tribune.com.pk/story/ 549510/bouquet-diplomacy-nawaz-offers-imran-accepts-hatchet-burying-offer/ (accessed 15 May 2013).

32. "PTI, JI, QWP join hands to form govt in KPK," Sajid Zia and Abrar Saeed, 14 May 2013, Nation, Lahore, http://www.nation.com.pk/pakistan-news-newspaper-daily-english-online/national/14-May-2013/ pti-ji-qwp-join-hands-to-formgovt-in-kpk (accessed 15 May 2013).

33. Imran Khan, Pakistan: A Personal History (London: Bantam Press, 2011).

34. http://www.ualberta.ca/ rnoor/aitchison_college.html (accessed 15 May 2013).

35. http://en.wikipedia.org/wiki/Pakistan_Tehreek-e-Insaf (accessed 15 May 2013).

36. "I almost lost the will to live': Imran Khan reveals torment over break-up of his marriage to Jemima Goldsmith," Craig Mackenzie, 26 Nov. 2011, Mail Online, London. http://www.dailymail.co.uk/news/ article-2066533/Imran-Khanreveals-torment-break-Jemima-Goldsmith-marriage.html\#ixzz2TNkc4Kig (accessed 15 May 2013).

37. "Pakistan's total debt reaches [US]\$130bn," 28 Feb. 2012, Dawn, Karachi, http://dawn.com/2012/02/28/pakistans-total-debt-reaches-130bn/ (accessed 15 May 2013).

38. "PTI will shoot drones down once in power: Imran Khan," Ferya Ilyas/Iftikhar Firdous, 10 Feb. 2012, Express Tribune, Lahore, http://tribune.com.pk/story/ 334469/pti-will-shoot-drones-down-once-in-power-imran-khan/ (accessed 15 May 2013).

39. "Obama wishes to meet Nawaz soon,” Dawn.com, Karachi, 14 May 2013, http://dawn.com/2013/05/14/obama-wishes-to-meet-nawaz-soon/ (accessed 15 May 2013). 
40. "Cameron praises Nawaz Sharif for economic aims," Daily Times, Lahore, 14 May 2013. http://www.dailytimes. com.pk/default.asp?page $=2013 \% 5 \mathrm{C} 05 \%$ 5C14\%5Cstory_14-5-2013_pg7_5 (accessed 15 May 2013).

41. "Kerry to arrive with new drone plan next month," Shaiq Hussain, Pakistan Today, Lahore, 17 May 2013, http://www.pakistantoday.com.pk/2013/05/16/ news/national/kerry-to-arrive-with-new-drone-plan-next-month/ (accessed 17 May 2013).

42. "John Kerry congratulates Nawaz, hoping to visit Pakistan soon," News Network International, 14 May 2013, http://www. nation.com.pk/pakistan-newsnewspaper-daily-english-online/islamabad/14-May-2013/john-kerry-congratulates -nawaz-hoping-to-visit-pakistan-soon (accessed 15 May 2013).

43. "UK funds poll in Pakistan on US drone attacks," Jamie Doward, Guardian, London, 18 May 12013. http://www.guardian.co.uk/ world/2013/may/18/polldrone-attacks-pakistan (accessed 19 May 2013).

44. "UK operates first drone strike from own territory," 2 May 2013, RT.com, UK. http://rt.com/news/uk-drone-afghanistan-reaper-731/ (see also: http://www.bbc. co.uk/news/uk-england-lincolnshire-22320275) (accessed 19 May 2013).

45. "Political parties name their own family members for reserved seats," Tariq Butt, The News, Karachi, 24 Apr. 2013, http://www.thenews.com.pk/Todays-News2-173212-Political-parties-name-their-own-family-members-for-reserved-seats (accessed 20 May 2013). See also "Democracy at its best: Kith and kin grab a lion's share of PML-N tickets," Tayyab Hussain, 16 Apr. 2013, Pakistan Today, Lahore (accessed 15 May 2013), http://www.pakistantoday.com.pk/2013/04/ 16/news/national/democracy-at-its-best-kith-and-kin-grab-a-lions-share-of-pmln-tickets/\#sthash.KMshO53K.dpuf.

46. “Gilani's two sons, brother get PPP tickets," Dawn.com, Karachi, Syed Irfan Raza, 13 Apr. 2013, http://dawn.com/2013/04/13/gilanis-two-sons-brother-getppp-tickets/ (accessed 15 May 2013).

47. "PPP stalwarts move petition against intra-party polls," Usman Manzoor, 2 Mar. 2013, The News, Karachi, http://www. thenews. com.pk/Todays-News-2162981-PPP-stalwarts-move-petition-against-intra-party-polls (accessed 15 May 2013).

48. According to one estimate: “300,000 plus @ PTI Lahore Jalsa - Live Forum Coverage," Pakistan Defence, 30 Oct. 2011, http://www.defence.pk/forums/ national-political-issues/121783-300-000-plus-pti-lahore-jalsa-live-forumcoverage-11.html\#ixzz2TNgMcP6H (accessed 15 May 2013).

49. "Imran's cousin Niazi contesting against PTI nominee," Tariq Butt, 4 May 2013, News, Karachi, http://www.thenews.com.pk/Todays-News-2-175265Imrans-cousin-Niazi-contesting-against-PTI-nominee (accessed 15 May 2013).

50 "Pakistan elections: How Nawaz Sharif beat Imran Khan and what happens next," Mohammed Hanif, Guardian, 13 May 2013. http://www.guardian.co.uk/world/ 2013/may/13/pakistan-elections-nawaz-sharif-imran-khan (accessed 15 May 2013). 
51. "Nawaz promises $\$ 10 \mathrm{~b}$ bullet train," Abdul Mujib Zahid and M. Irtaza, Nation, Lahore, 4 May 2013, http://www.nation.com.pk/pakistan-news-newspaperdaily-english-online/national/04-May-2013/nawaz-promises-10b-bullet-train (accessed 15 May 2013).

52. “Aid Addiction,” Naseer Memon, 15 May 2013, http://tribune.com.pk/story/ 549776/aid-addiction/ (accessed 15 May 2013).

53. Khan, Pakistan.

54. "Former Engro CEO Asad Umar joins PTI," Express Tribune, 18 Apr. 2012, Karachi, http://tribune.com.pk/story/366422/former-engro-ceo-asad-umar-joinspti/ (accessed 15 May 2013).

55. "Game changers: Imran injects 'fresh blood' into national politics," Zahid Gishkori, 16 Apr. 2013, http://tribune.com.pk/story/536149/game-changersimran-injects-fresh-blood-into-national-politics/ (accessed 15 May 2013).

56. "Feudal Bonds Grip Pakistan Rural Vote in Bar for Landowner Tax," Haris Anwar and Khurrum Anis, Bloomberg.com, 7 May 2013, http://www.bloomberg.com/ news/2013-05-07/feudal-bonds-grip-pakistan-rural-vote-in-bar-for-landownertax.html (accessed 16 May 2013).

57. Imran Khan (PTI), "Last Full Election Speech From Shoukat Khanum Hospital [Lahore] (D-Chowk [Islamabad]," http://www.youtube.com/watch? $=$ bDIoFt2K88g (accessed 9 May 2013). 